\title{
Establishment of Marathas power in Bundelkhand \& Effects
}

\author{
**Dr. Shobha Pandey, *Dr.Mohammad Aarif Rayeen
}

\begin{abstract}
Bundelkhand situated Uttar Pradesh \& Madhya Pradesh in Jhansi, Jalaun, Hamirpur, Mahoba, Banda and Lalitpur Districts \& Datia, Tikamgarh, Chhatarpur, Panna, Sagar and damoh. During the reign of Emperor Akbar(1556-1605AD) the greater part of eastern Bundelkhand where Maharaja CHHATRASAL of Panna(1649-1731AD) later acquired predominance formed a portion of the Moghal subah of Allahabad. Mohammad khan Bangash became the Subahdar of Allahabad. Mohammad khan Bangash crossed the Yamuna foe second time in January 1727AD. Near Allahabad and pushed himself vigorously into the eastern Bundelkhand. He subdued and conquered the extensive tract spreading over 200 miles in between Luk and Banda.To sume up, the Bangous-Bundela war, which lasted about to and a half years, brought the kingdom the Chhatrasal almost to the brink of ruin. Jaitpur had fallen to the Bangash and chhatrasal had to Surendra along with his family to the enemy. In such moments of great despcir, Chhatrasal like drowning man clutching at every straw, had appealed to Peshwa Bajirao I to rush to his rescue. Bajirao speedily arrived in Bundelkhand, forced Mohammad Khan Bungash to fight with back to the wall, and though he left a little before the completion of the siege of Jaitpur, Chhatrasal was well equipped to force the Bungash to evacuate the fort and made his exit from Bundelkhand. after the death of Chhatrasal (4december1731AD) this kingdom was to be devided mainly between his two sons, Hirdes Shah \& Jagat Raj and Peshwa Bajirao. I whom he head adopted as his third son. However Bajirao did not like to go to extremes to enforce his claims to the one third portion of the kingdom of Chhatrasal, he rather preferred peaceful negotiations extending over a long period till his death. The reasons were not for to seek. The Marathas had acquired a foothold in the Bundela country and Bajirao wanted to develop it into a full fledged base for his ambitious operations in the north.
\end{abstract}

Bundelkhand situated as it is in the heart of the India sub continent, has been a cultural and linguistic entity with its well defined geographical limits and historical past. Presently it stands divided between the Jhansi, Jalaun, Hamirpur, Mahoba, Banda and Lalitpur Districts \& Datia, Tikamgarh, Chhatarpur, Panna, Sagar and damoh of Madhaya Pradesh.

During the reign of Emperor Akbar(1556-1605AD) the greater part of eastern Bundelkhand where Maharaja CHHATRASAL of Panna(1649-1731AD) later acquired predominance formed a portion of the Moghal subah of Allahabad. Chhatrasal and his brother were denied support and shelter in Bundelkhand even by their close relatives who were afraid of incurring the wrath of enemies of Champat, who than abound in the region. Therefor Chhatrasal his elder brother Angad and their uncle Jamshah joined of service of Mirja Raja Jay Singh who was then leading the Mughal campaign against Shivaji in Maharashtra. They fought in the siege of the Purandhar(1665AD) and on the recommendations of Jay singh received petty mansabs whitch left them disgusted. Chhatrasal remained with Shivaji for something. He learn the art of Gorilla warfare and statecraft from his preceptor and finally on hispromtings returned to Bundelkhand to uproot the Mughals and found a kingdom of his own in the region. Mohammad khan Bangash became the Subahdar of Allahabad in December 1720AD. And received assingnments on Kalpi and Earch which were held by Chhartasal. They now started brewing up. In $1720 \mathrm{AD}$. The Bundelas

* Bundelkhand PG College, Jhansi

* Maa Chandrika Mahila Degree College, Mahoba(Uttar Pradesh) INDIA

caused trouble around Kalpi and Jalalpur. Dilerkhan, a chela of Bangash tried to subdue them his efforts met with success, but ultimately the Bundelas uinder Chhatrasal hunted him down at Maudhah and killed him an uneven contest on the 15 may 1721AD. Chhatrasal had previously offended Emperor Mohammad Shah by his active support to Girdhar Bahadur the rebellious governor of Allahabad and the rebel Khichi zamidar of Ashothar.

The Bundelas under HirdeshShah, a son of Chhatrasal overren Baghelkhand in 1726AD. And Mohammad Khan Bangash was once again directed to under take operations agains them. He crossed the Yamuna foe second time in January 1727AD. Near Allahabad and pushed himself vigorously into the eastern Bundelkhand. He subdued and conquered the extensive tract spreading over 200 miles in between Luk and Banda. 


\section{Bajirao in Bundelkhand}

Peshwa Bajirao prior to his entry into in Bundelkhand was campaigning in Deogarh. He was herdpressed by his creditors, and was anxiously looking for fresh avenues to augment his dwinding financial recources, which were causing great concern to his master Chhatrapati Shahu. He therefore readily grasped at the opportunity to promote the territorial and pecuniary interests of the Marathas in Bundelkhand. His brother Chimaji Appa by his victory over the imperial governor Girdhar Bahardur in bettle of Amjhera (29 nov.1728AD) had already established the Maratha predominance in the Sabha Of Malwa. Bundelkhand lay adjacent to it, The possibily of using both the regions as bases and the spring board for the Maratha expansion in the north, must have also stirred the imagination of the ambitious Peshwa. All this coupled with the lure to play the deliverer, inspired Bajirao to under take the Bundelkhand expedition to the rescue of Chhatrasal Bundela.

Bajirao negotiated a peace with the Raja of Deogarh and arrived at Khijri in Bundelkhand on the six March 1729AD. His army then consisted of about 25000 horsemen and was commended by twelve young Sardars of whom Pilaji Jadhav Neroshankar, Tukoji pawar and Dewalji Somevansi were the important onces. Bajirao lost no time. He informed Chhatrasal to his arrival and resumed his onward march. Passing through Pawai and Rajgarh he arrived at Mahoba on the 12 march. Chhatrasal visited the Peshwa on the 13 \& 17 March mutual countries the present were exchang and a joined plan of oprations as eveolved.

To sume up, the Bangous-Bundela war, which lasted about to and a half years, brought the kingdom the Chhatrasal almost to the brink of ruin. Jaitpur had fallen to the Bangash and chhatrasal had to Surendra along with his family to the enemy. How galling and humiliating it must have been to the octagenerian Bundela chief to watch the fabric of his kingdom of Panna, which he had built up after a long struggle of 60 years, crumbling down at the fag end of his life. The Future looked bleak and hopeless. In such moments of great despcir, Chhatrasal like drowning man clutching at every straw, had appealed to Peshwa Bajirao I to rush to his rescue. Bajirao speedily arrived in Bundelkhand, forced Mohammad Khan Bungash to fight with back to the wall, and though he left a little before the completion of the siege of Jaitpur, Chhatrasal was well equipped to force the Bungash to evacuate the fort and made his exit from Bundelkhand.

What a strange coincidence it was that a son of Maharastra, the great Shivaji had inspired Chhatrasal to wage a relentless struggle against the Mughals, while another, Bajirao I had saved him and his kingdom from extinction!

Chhatrasal gratitude knew no bounds. He declared Peshwa Bajirao I had adopted son and bequeathed him one thired portion of his kingdom. Chhatrasal was shrewed enough to comprehend the kingdom. Chhatrasal shrewd enough comprehend the significance of a close alliance with the Marathas under the dashing leader Bajirao in those time of strain of stress. Chhatrasal 's bequest secured Marathas support and protection to his descendants on the one hand, while on the other it provited the Marathas with a foothold in Bundelkhand, an era rapid extansion of the Marathas Power influence over the region, which forms the subject matter of the subsequent chapters.

\section{Partition of Chhatrasal's kingdom}

Chhatrasal did not survive long after the conclution on the Bungash-Bundela war, he breathed his last on the forth december1731AD. But before his death he had addressed a letter (nov.11,1730) to his trusted ministers at Panna in which he gave them some define instruction about the partition of his kingdom was first to be partitioned between his to sons Hirdes shah and Jagat Raj at the ratio of one and one fourth and three quarters respectively, and them the both were required to hand over one thired of their respective territories to the Peshwa BajiraoI.

Chhatrasal 's kingdom which was then known as Dangaiya Rajya extended roughly from Kalpi in the north of sironj and saugar in the south. Towards the east it touched the borders of Bondelkhand and inclubed jaso and birsingpur, while on the west, its frontiers were adjacent to those of the Bundelas states of Orchha \& Datia. Thus within its fold lay the modern districts of Hamirpur, Jalon \& Banda and a part of Jhansi Distric of Uttar Pradesh, while the states of Panna Ajaygarh, Chhatarpur, Bijavar, Sagar, Sarila, Jigni, Alipur etc. which have been lately merged in Madhya Pradesh, were in reality the off shoots of the Chhatrasali Rajya. Now after the death of Chhatrasal (4december1731AD) this kingdom was to be devided mainly between his two sons, Hirdes Shah \& Jagat Raj and Peshwa Bajirao. I whom he head adopted as his third son. According to pogson, under the final settlement Kalpi, Hattha, Sagar, Jhansi, Sirong, Konch, \& Garhakota fell to the share of the Peshwa, while Hirdesh Shah received Panna, Kalinjar, Mau, Erach, Dhahmoni etc. and JagatRaj was assigned Jaitpur, Ajaygarh, Charkhari, Bhuragarh \& Banda in their respective shares. The revenues of the territories of Hirsesh Shah amounted to Rs. 3846123 as. 13 p. 10 \& JagatRaj's possessions yielded a revenue of Rs. 30,76953 as.1p.1. the revenue of the Peshwa's portion were the same as those of Jagat Raj i.e.Rs.3076953 as.p.1. B. 


\section{Bajirao negotiates for settlement}

After the death of Chhatrasal, Bajirao started negotiates with Hirdesh Shah \& Jagat Raj to settle his claims. The letter two agreed to hend over the territories worth two lacs to the Peshwa as an instalment of his share from their respective kingdoms and Bajirao and his brother Chimaji Appa executed a deed of acceptance on the seven aprial 1732AD. This deed was in the nature of an egriment between Bajirao and Chimaji Appa on the onehend and Hirdesh Shah and JagatRaj on the other and contained the folling important points of aggrement-

(1) Both the Parties to render military assistance to each other whenever needed.

(2) If joint campaign was undertaken in the imperial dominions or in some other territories with motives of gain and plunder, then it was to the proportion of the respaective forces participating therein.

(3) If in such campaigns some territories were occupied or acquired and the strength of the army of both of the combining parties was equal then they were to be shared half and half.

(4) If the Mughal Emperor would grant Chauth or Sardeshmukhgi of some Subah of territories adjacent to the kingdoms of the to Bundela brothers, then the latter two would collect the dues for the Peshwa.

(5) No Maratha army would ever enter in their territories without their prior consent.

(6) No deserters from their respective courts or kingdoms would be entertained at Maratha Court.

Soon after Bajirao appointed one Mudhoji Hari as his agent to secure the partitioned territories and look after his interests in Bundelkhand. However the procrastinating attitude of Hirdeshah and Jagatraj delayed the actual handing over of the promised territories and it was only when Peshwa Baajirao dispatched Chimaji Appa in October 1732 to Bundelkhand that some notable progress in this direction was made. Chimaji Appa by exerting pressure on Hirdeshah and Jagatraj secured from them a title deed to the territories yielding two lacks. Cordial relation were now revied and Chimaji presented a she elephant to Hirdesh Shah and some what later an elephant to Jagatraj. Chimaji appointed Govind Ballal Kher who was in his territories and made arrangements for the payment of the revenues. Govind Ballal had accompanied Bajirao I in his campaign against the Bangash in Bundelkhand and had acquired a certain amount of knowledge of the local condition due to which Chimpaji deemed his appointment to be suitable. Govind Ballal or Govind Pant exerted himself sedulously and within a short time of two months made settlements with a number of villages, which yielded a revenue of 50 to 55 thousand. His commendable work prompted Chimaji Appa to urge the recall of Mudhoji Hari, the former agent of Peshwa who had been unable to effect much as his assignment overlapped that of Govind Ballal. Chimaji then proceed to Orchha and Datia and extorted arrears of tribute which he forwarded to the Peshwa via Sironj. Govind Ballal by his persuasive methods secured territories worth one and quarter lacs from Hirdeshah along with the fort of Rajgarh and territories worth a lac from Jagatraj. Hirdeshah also very candidly agreed to make up the deficiency if the revenues of the ceded territories amounted to less than one and a quarter lacs. As a matter of fact Hirdeshah was really anxious to cultivate closer relations with Peshwa Bajirao for he coveted the hoarded treasures and the territories of Orchha and Datia, since they lay adjacent to his kingdom. Therefore, he promised Peshwa all possible help in his north Indian campaigns, in Byundelkhand or beyond and offered to join him even in his expeditions to Allahabad and Delhi on the terms of sharing the booty and the territories half and half.

Peshwa Bajirao I was kept well informed of the imperial designs by his agents at Delhi. He now thought it prudent to take time by forelock and initiate the moves himself. Accordingly he left Poona on $8^{\text {th }}$ October 1735 at the head of a big army along with Holkar, Sindhia Anand Rao and Tukoji Pawar and Kanthaji Kadam etc. A part time of his army was sent a head to Bundelkhand in Nov.1735 under Satvoji Jadhav, the son of Pilaji Jadhav and Baji Bhivro. Pilaji did not himself accompany this force as he was then lying ill and the Persian authorities which refer to hisparticipation in this expedition, mistook Satwoj for him.

\section{Concluding remarks}

The foregoing pages reveal that nearly in all the northern campaigns undertaken in or beyond Bundelkhand in the territories of Bhiad and Bhadawar in between1732-38 either by the peshwa Bajirao I and Chimaji Appa or by their Sardars, the successors of Chhatrasal, Hirdesh and JagatRaj actively assisted the Marathas with men and material. The only exception being the operation against the Nizam, when overawed by his grand army they sent, under compultion, a Bundela contingent to join him, as may be guessed, much against their will. Peshwa Bajirao rightly understood their dilemma and after his striking success at Bhopal did not take their temporary desertion seriously.

Thus, on the whole, the relations between the Peshwa Bajirao and the successors of Chhatrasal, Hirdeshah and Jagatraj, remained cordial and cooperative. However at times the Peshwa became a little impatient with them due to their apathy towards the partition of the kingdom of Chhatrasal and finally handing over the share of the Peshwa. Their procrastinating attitude drew censorious remarks from the Peshwa, though couched in polite and diplomatic language. For example, in a letter to Hirdesh dated $12^{\text {th }}$ February 1734 demanded an early completion of the partition. However Bajirao did not like to go to extremes to enforce his 
claims to the one third portion of the kingdom of Chhatrasal, he rather preferred peaceful negotiations extending over a long period till his death. The reasons were not for to seek. The Marathas had acquired a foothold in the Bundela country and Bajirao wanted to develop it into a full fledged base for his ambitious operations in the north. In his designs he needed staunch and reliable allies in the region who could keep him well supplied with the senews of war and not only guard his rear, but also keep the road to the Deccan open only for the retreating Maratha hords when exhausted or overburdened with the loot and the plunder. Who else could serve the Peshwa better than Hirdeshah and Jagatraj, the sons of his adoptive father Chhatrasal Bundela?

However Bajirao's relations with the Rajas of Orchha and Datia were not so cordial. Both of them were traditionally, hostile to the house of Panna and imperialists to the back bone. Their in the suppression of the 'Rebel Champat' and their antipathy towards Chhatrasal are well established facts. Andneedless to add that Marathas into Bundelkhand, which boded ill for them. Therefore they displayed marked hostility towards the Marathas and nearly always willingly cooprated with the Mughals, whose most loyal vassals they were, against them. Then how could Bajirao treat them at par with the descendants of Chhatrasal? Therefore he or his generals like Chimaji Appa, Pilaji Jadhav, Baji Bhivarao etc. whenever campaigning in or through Bundelkhand extorted heavy tributes from them remorselessly, occupied their territories and punished them for their lapses. This further aggravated the situation and though the Rajas were cowed down by the superior force, they never willingly submitted to it. They sullenly brooded over the wrongs done to them by the Marathas and whenever an imperial general like the Wazir Qamaruddin Khan or the Nizam took the field against them, they joined him and were later punished by the Marathas for it. This vicious circle went on and on and the relations between the Marathas and the two chief Bundela states of Datia and Orchha could never be cordial.To sum up, while Bajirao maintained cordial relations with the descendants of Chhatrasal, he could not win over the Rajas of Orchha and Datia to the Maratha side and though he and his Sardars kept thm suppressed, the latter turned upon them viciously whenever their strange-hold loosened a little.

\section{References}

[1]. Tlwari, Gorelal Bundelkhand ka Sanchhipta Itihas, pracharni sabha Kashi,1990.

[2]. Lal, Shayam Tarikh-a-Bundelkhand, Nowgong(MP), 1884.

[3]. Chandra,Satish Parties \& Politics at the Mughal court,AMU,Aligarh.1959.

[4]. Sardesai,G.S. New history of the Marathas Vol.I,Vol.IIVol.III, 1948,1957.

[5]. Sharma,D \&Banatsidas Early Chauhan Dynasties, Delhi, 1975.

[6]. Compton,Herbert European Military Adventures, Oxford University press, Karachi.1967.

[7]. Historical papers of sindhis of Gwalior, Vol.I(1934), Vol.II(1940).

[8]. Asiatic Annual Registers.

[9]. Journal of the Asiatic Sociaty of Bengal.

[10]. Orchha State Gazatter, Datia State Gazatter, Panna State Gazatter, Central India State Gazatter, Jhansi State Gazatter(1907). 